\title{
Geographies of Oppression-The Cross-Border Politics of (M)othering: The Break of Day and A Yearning
}

\section{ELAINE ASTON}

In the autumn of 1995 the Haymarket Theatre, Leicester, UK, staged two plays which offer a dramatic treatment of the politics of motherhood: Timberlake Wertenbaker's The Break of Day (Haymarket Mainhouse, first performance 26 October 1995) and Ruth Carter's A Yearning (Haymarket Studio, 31 October to 4 November 1995). Neither play had significant box-office success, ${ }^{1}$ and The Break of Day received poor and hostile reviews from (male) critics, many of whom, like Paul Taylor for The Independent, commented on the play as a dramatization of how the maternal drive can cause women to betray orthodox feminism'. ${ }^{2}$ My counter argument is that by addressing infertility as a feminist issue for the 1990s, both plays index the need to re-conceive a politics of motherhood in an international arena, highlighting the ways in which the biological contours of women's lives are globally mapped with the specificities of social, material and cultural geographies.

\section{The Break of Day}

Wertenbaker's The Break of Day was performed in tandem with Chekhov's Three Sisters by Max Stafford-Clark's Out of Joint company. Wertenbaker's three 'sisters', at the close of this century, are three 'successful' women-Tess, Nina and April-whose lives were influenced by the Women's Liberation Movement in the 1970s. ${ }^{3}$ Act One has a Chekhovian feel: a house in the country where the women, accompanied by husbands or lovers, gather together for Tess's fortieth birthday party, talk about their lives, and in particular examine their middle-class feminist aspirations of the post-liberation years. Tess, now a high-flying editor of a glossy women's magazine, Nina, a singer-song writer, and April, a university lecturer, are dissatisfied with professional and personal 'achievements'. None has children: April is childless by choice; Tess and Nina both desire but cannot have children. The play explores the different ways in which Nina and Tess struggle to bring children into their lives.

The emotional intensity with which Tess and Nina talk about their infertility and the desire to have children, coupled with their discussion of feminism-in particular the loss of empowerment which the feminist climate of the 1970 s gave them-may suggest, on the surface, a backlash play. But in staging this moment of nonreproductive realization for a particular generation of white, middle-class, economically privileged, Western women, Wertenbaker does not embark on a 'betrayal of orthodox feminism', but rather opens up a complex, materialistfeminist debate on mothering, the family and nationalism.

Wertenbaker explains her concern in The Break of Day to write about 'the fatigue at the end of the century, the breakdown of a lot of ideals, particularly for women' ${ }^{4}$ In her play, England in the 1990s is characterized as a country in which feminism is eroded and social systems-health, education and welfare-are in a state of collapse. The possibility 
of a more 'democratic opening', 5 of moving beyond the millennium moment of 'fatigue' and 'breakdown', requires thinking beyond an English, nationalist, isolationist, 'island mentality $^{\prime}{ }^{6}$ A Brechtian-inflected montage of short quick-changing scenes is used to relocate from the opening, country house realist setting in England, to the chaos of a post-Communist society opening up to capitalism somewhere (precisely where is never specified) in Eastern Europe, as Nina and her record-producing husband, Hugh, struggle to adopt an abandoned baby. The geographical and locational shifts between Acts One and Two are central to Wertenbaker's vision, or rather glimpse, of a new, more democratically organized society, conceived of globally, rather than nationally, and offering a more hopeful political solution to women's personal, maternal lives.

Hope for the future is represented in the figure of the cross-border child, explained in what is arguably the play's most important and most memorable speech, delivered as a monologue by the East European Mihail, who refuses to 'recant' his Communism:

Now it [history] will be in the hands of the children, possibly most of all, these cross-border children I have helped to get out. Born in one country, loved and raised in another, I hope they will not descend into narrow ethnic identification, but that they will be wilfully international, part of a great European community ... We must not go into the next century with no ideal but selfishness. ${ }^{7}$

The cross-border child represents a concept of the family based not on nation, but on 'community', one which crosses borders and involves the collaboration between two sets of beliefs: Western feminism and Eastern Communism, both struggling to find a way to exist in allegedly 'democratic', 'post-feminist' and 'post-Communist' communities; struggling to find a selfless way forward in a world which, as Mihail describes, has 'no ideal but selfishness', and where 'people talk freely, but only about money' (pp. 82-3). In working together to secure a future for the child, Hugh and Nina from the West, Mihail and his wife, Eva, from the East, find ways to circumvent, manipulate and resist the local, social and legal systems which stand in their way, in whatever ways they can, including, for example, the Western, bour- geois appeal to the heart. ${ }^{8}$ The collaboration and resistance of this small group of people point to the need for a large-scale, cross-border collaboration to achieve social and cultural transformation. ${ }^{9}$

The gender of the cross-border child (a girl) is highly significant. In the moment of $A$ Break of Day's production, the issue of overseas adoption-or transracial adoption, as Wertenbaker's social worker in Act Three terms it, ${ }^{10}$-was headline news, as couples in the UK and US adopted baby girls from China. ${ }^{11}$ The issue of unwanted female children in China received widespread publicity in the UK following the television documentary The Dying Rooms (June 1995) which alleged that in a country which restricts families to one child, making boys the priority, the girls are abandoned and left to die in orphanages. ${ }^{22}$ The plight of the children tugged at the heart strings in a way which, although understandable, threatened to overshadow the specificity of the social, political and economic conditions which had given rise to this terrible situation. Similarly, there is a danger in Wertenbaker's play, as the spectator is hooked into and carried away by the suspense of whether or not Nina will succeed in her mission to save the child, of sentimentalizing what in other ways she seeks to establish as a materialist-feminist critique of capitalism 'birthing' an unequal and exploitative future.

That it is Mihail, the unreformed Communist, who is largely responsible for Nina and Hugh finally acquiring their baby girl is significant. Mihail's anti-capitalist attitude signals that his motive for helping the childless British couple is selfless rather than selfish; that he is not one of the businessmen profiting from the trading in babies. ${ }^{13}$ Wertenbaker underlines this point by intercutting the East-West post-feminist, post-Communist struggle for a 'future', with Tess who tries a different route for a baby. She seeks infertility treatment from the ironically named Dr Glad. Her struggle to conceive highlights the financial, physical and emotional cost to women who pursue fertility treatment through reproductive technology, owned and operated by men. Tess loses control over her own body, is disempowered by the intervention of technology, and after all her physical and emotional pain, has no baby to show for it. 
Nina's adoption quest reveals that there are other options. This is not to suggest clear-cut 'right' and 'wrong' solutions. While, on the one hand, Wertenbaker implies a criticism of Tess's white, middle-class, materially advantaged, bourgeois feminist position, on the other hand, she is resistant to the idea that the audience sit in judgement. Tess, in a self-defensive moment in Act Three, cries: 'Don't judge me! (More quietly.) I see myself.' (p. 91) (14 $^{14}$

What is clear, however, is that it is necessary to move out of the isolated, English country house and a colonial past which continues to 'birth' an unequal future; which may choose whether to give shelter to, but cannot provide a 'home' for, the displaced 'other'. ${ }^{15}$ The biological mother who haunts the figure of the crossborder child, an absent/present, colonized 'other', might come differently into view in a cross-border community where families re-form across geographies landscaped through greater gender and racial equality.

\section{A Yearning}

Like The Break of Day, Ruth Carter's A Yearning, performed by the Asian theatre company Tamasha, revisits and revisions a 'canonical' text as it engages with the debate on motherhood and the issue of infertility. A Yearning transposes Lorca's Andalusian landscape and speech of Yerma to a multicultural, Punjabi community in Birmingham. Amar (Yerma) is now married to Jas (Juan), a Glaswegian Asian who struggles not on the land but with a taxi firm. As in Yerma, A Yearning focuses on Amar's desire for a child, which unfolds as a narrative of increasing desperation and despair, and finally drives her to kill her husband.

My initial response to the performance of $A$ Yearning was a highly charged emotional reaction to Amar's desperation for a child, coloured by my own white feminism and fertility. The anguish of infertility played out in the performance was what touched me first and foremost. For instance, I was deeply affected by the moment when Amar, surrounded by child-bearing women from her community, cries out:
You women with children you can't imagine what it's like for us without. You 'wish I wouldn't talk like this'. It shows you're ignorant of the pain inside me, like a fish swimming in water that has no idea what thirst is. Because what you don't understand is that it doesn't get better. I want it more and more and the longer it goes on the less hope there is. ${ }^{16}$

Subsequently, however, I found I needed to contest this response and to re-frame my initial reactions to Amar's childless body through the concerns of black British feminism. ${ }^{17}$ Looked at in this way, then, it is a black feminist critique of the social, cultural and religious organization of an Asian community and its familial structures which come more firmly into focus through the infertility motif. This may be examined through the triangular positioning of Amar, Jas and the community of Asian women.

Amar is representative of another kind of cross-border figure: a young woman who crosses from her Punjabi birthplace in India to live in a Punjabi community in Britain, which, as Kristine Landon-Smith, Tamasha's director, explains, can be more conservative than in India: 'The Punjabi community in Britain does not seem to have lost connection with its rural roots. It is almost as though the community, in an effort to retain its culture against a foreign landscape, is even more traditional than the Punjabi community in Indian society today. ${ }^{18}$ The crossing between communities, or worlds, is encoded in Amar's speech and songs. When Amar sings at her sewing machine (a recurrent motif to signal her domestic entrapment) her songs switch between Punjabi and English. To the Western ear, her speech patterns sound lyrical or poetic, but Kristine Landon-Smith explains that in Punjabi (as in Lorca's Andalusian peasant communityl 'metaphorical speech is natural and therefore when written down it is meant to be an authentic representation of that speech and not poetic text'. ${ }^{\prime 9}$

As Amar is forced into the traditional ways dictated by her cultural, religious and social background, she effectively becomes a prisoner in her own home. She tries to escape from the house into the city streets, but each time she 'escapes', she is brought home by her husband 
(and his sisters who are sent to keep an eye on her) and chastised for her 'improper' behaviour, and for 'spoiling' his reputation. As Pragna Patel explains in her discussion of Asian women and third wave feminism, 'women's minds and bodies are the battleground for the preservation of religious and communal identities. So the role of women as signifiers and transmitters of identity within the family become crucial. ${ }^{20}$

A Yearning shows, and is critical of, the extent to which the identity of the young Asian wife is bound up in a maternal identity. Amar's lack of self-worth is rooted in her 'failure' to conceive, to become a mother: 'A Punjabi girl who doesn't produce sons-she is as useless as a handful of husks. Empty and useless.' (p. 41) The pressure on young Asian women to conceive early in marriage was researched for the play through women's organizations. One Asian reviewer explained that:

According to Neeru Desai, chairman of the Harrow Women's Association, a community group in North London, there is pressure on the young wife to produce the first child fairly quickly. 'If after a year or two of marriage, there isn't a child, people start asking questions. It's usually the women's fault, even if in medical terms it isn't..$^{\prime 21}$

Rather than face the fact that it is his fault that they cannot have children, Jas irrationally accuses Amar of promiscuity, madness and evil. Amar protests that she is 'blameless', but Jas does not listen. He is obsessed with the way in which her 'infertility' alters his standing in the community: 'I enter the office everybody goes quiet. I order a drink I get a funny look. My regular customers, they're not friendly like they used to be with me. They're not easy. There's a look in their eye. Why? You tell me why?' (p. 51)

Amar is oppressed not just by her Indian past in the Punjab, but also by the multicultural values of the Punjabi community in Britain. In Britain, multiculturalism appears to suggest the redefinition of culture along the lines of ethnic diversity and difference, but in reality, diversity and difference exist only in relation to, or defined by the hegemony of white, dominant culture. ${ }^{22}$ Moreover, as Patel argues, this inequitable arrangement between dominant and minority cultures creates the opportunity for

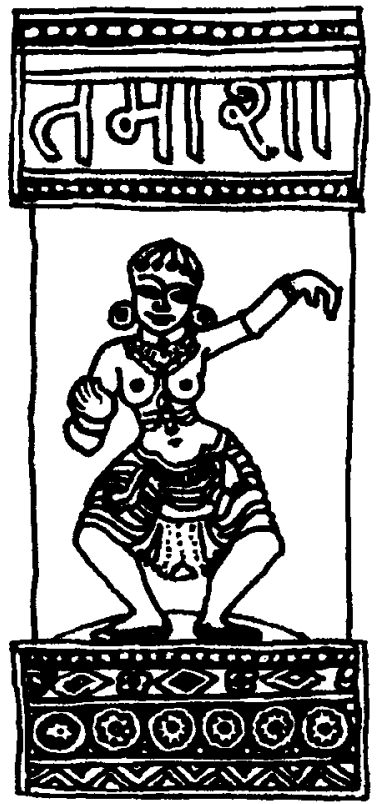

The logo of Tamasha Theatre Company

'community leaders' to act as 'power-brokers and middle-men' between state and minority communities. Such male 'leaders', however, will not be seeking to promote the rights of women. ${ }^{23}$ Jas, who internalizes the white conservative values of his multicultural Punjabi community, is driven by the need to be financially successful in his taxi business. He can cope with the absence of a child providing that Amar keeps out of sight in the home. Secluded in her domestic prison, she is the slave, the colonized 'other', who endorses his position as colonizer/master. Her refusal, however, threatens to undo the binarism of the master/slave arrangement, to expose the impotence of his patriarchal 'mastery' through which the image of the British-Asian family is constructed and upheld. In brief, A Yearning deconstructs what Patel describes as 'the construction of the homogenous Asian family' which 'hides other realities, power relations and power struggles between different caste, class and ethnic groups, and especially between men and women' (my emphasis, p. 261). Ultimately, as her Punjabi honour will not allow her to consider taking a lover, Amar takes the life of the oppressor who would not let her live: give her 


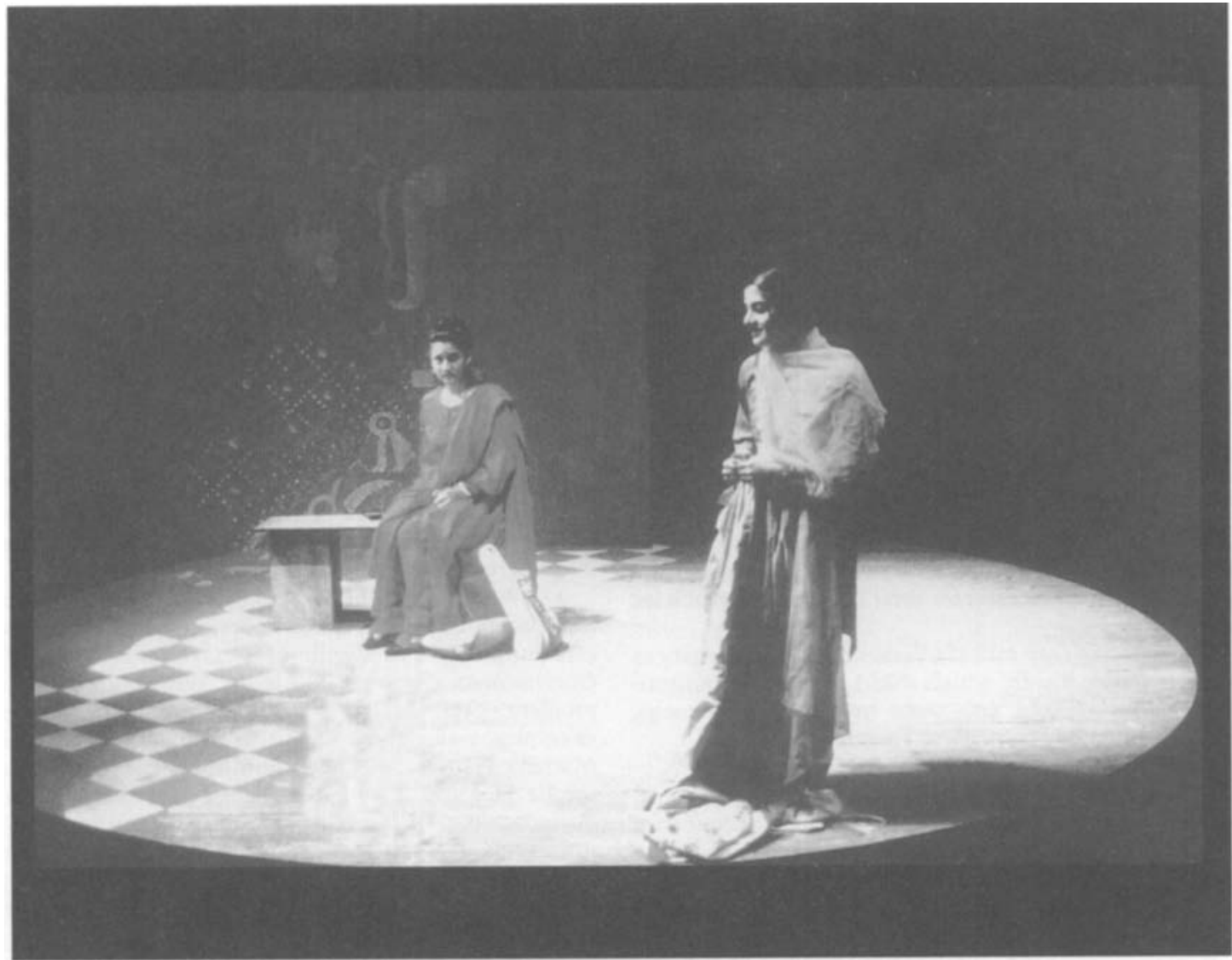

Archie Panjabi and Sudha Bhuchar (left to right) in A Yearning, 1995 (Рното: Sue Mayes)

life. This violent rebellion of the colonized 'other' is presented as the only alternative to a life of domestic subjugation. ${ }^{24}$

Other women from the community who figure in A Yearning function as a kind of chorusgossiping, criticizing, blaming. There are occasional notes of discontent as the Asian wives and mothers express a desire for an existence other than that of their stay-at-home routines of cooking samosas and watching Punjabi videos, but they have no choice. The strongest objection to the social construction of the Asian wife/mother from within the female community comes from the voice of the old woman, played in the production by the Indian actress Zohra Segal, now in her eighties. Against the expectation that the most senior representative of the female community will reflect the most traditional values, Segal's role sounded the most critical, feminist note. ${ }^{25}$ In her first encounter with Amar, the elderly Asian is critical of the system of arranged marriages which does not allow women to choose for themselves; and in their last meeting she proposes that Amar find another man to give her the child she desires, arguing that 'these are modern times' (p. 57). That both the role of the old woman and that of Amar were played by actresses familiar to theatregoers through their film and television work in the field of popular culture, is an important factor in trying to persuade audiences that these are 'modern times' and that the organization of the Asian family which ties women to a biological, maternal 'destiny' is in need of radical, social transformation. ${ }^{26}$

In her conclusion, Patel argues for the need to move beyond identity politics, in search of 'new ways of resisting and new ways of truly democratic thinking', most importantly arguing that 
'our alliances must cross our different identities, and help us to reconceptualize notions of democracy, human rights and citizenship' ${ }^{27}$ Wertenbaker's plea for a collaborative, cross-border, democratic re-modelling of national, social and familial structures, is not dissimilar. The diaspora of Amar's dispossessed and displaced body in the 'home' of British-Asian multiculturalism suggests the urgency with which feminists across borders need to find new meeting grounds to pursue and to develop these 'new ways of resisting and new ways of truly democratic thinking'.

\section{Notes}

I should like to thank Alison Altman (free-lance theatre practitioner and tutor), Tamasha Theatre Company and the Haymarket Theatre, Leicester for their help with research for this article.

1. The Break of Day sold 1263 seats over 9 performances compared to Three Sisters which sold 1120 over 2 performances. A Yearning sold 469 seats over 7 performances. Statistics supplied by Haymarket Theatre.

2. The Independent, 30 November 1995, p. 13.

3 . It is also interesting to note how the most 'typical attenders' for Haymarket productions (women) account for $70 \%$ of their audience profile, and are grouped largely in the age range $25-54$ years - this roughly approximates to Wertenbaker's forty-something generation of women. Statistics supplied by the Haymarket Theatre.

4. Wertenbaker, interview in Heidi Stephenson \& Natasha Langridge, eds., Rage and Reason (London: Methuen, 1997), p. 144.

5. I have taken 'democratic opening' from Honor FordSmith's account of the 1970s birth of Sistren, the Jamaican Women's organization, 'Ring Ding in a Tight Corner', in M. Jacqui Alexander \& Chandra Talpade Mohanty, eds., Feminist Genealogies, Colonial Legacies, Democratic Futures (London and New York: Routledge, 1997), pp. 21358. Ford-Smith qualifies 'democratic opening' as 'a moment in history in which there was a possibility for those who are oppressed to intervene in history and transform their society' (p. 217).

6. See Judith Johnson on England and its 'island mentality' in the afterword to her play Uganda, in Pamela Edwardes, ed., Frontline Intelligence 3: New Plays for the Nineties (London: Methuen, 1995), p. 133.

7. Timberlake Wertenbaker, The Break of Day (London: Faber, 1995), pp. 82-3.

8. For instance, in order to win over Dr Romanova at the Ministry of Health, Eva, a self-confessed 'ideologist of the heart', 'performs' in the style of a Western domestic melodrama, calling on her to have 'pity for the mother and child in this world full of pain' (p. 81).

9. There is a parallel to be drawn, I think, between the small group of people involved in the cross-border adoption and the small-scale touring company which Robert, Tess's husband, joins to play Vershinin in Chekhov's Three Sisters. (Act Three is set backstage in a northern provincial theatre on Robert's last night of the production, p. 89.) Both situations involve small groups of people committed to social and cultural 'causes', based on selfless rather than selfish principles. In respect of the Chekhov production, for example, it is made clear that this is a non-profit-making enterprise that very few people will go to see.

10. Overseas adoption is generally referred to in the UK as either transracial or intercultural. Explained to me by Alison Altman, telephone interview, 9 February 1998.

11. Earlier, in 1994, overseas adoption received media attention through the case of a British couple, Adrian and Bernadette Mooney, who were given a jail sentence (later suspended) for trying to smuggle a child out of Romania.

12. It was this programme which prompted Alison Altman to embark on the overseas adoption of her daughter, Rosa, a cross-border child who arrived in the UK in 1997. As a feminist, Altman was particularly distressed by the way in which it was the baby girls who, in China, are left to die. Altman, telephone interview, 9 February 1998.

13. While it would be wrong to assume that this is a phenomenon of all overseas adoption, contributors to Nanette Funk \& Magda Mueller, eds., Gender Politics and PostCommunism (London: Routledge, 1993) note that this is a problem specific to certain post-Communist countries. For example, writing on women in Romania in the volume, Mariana Hausleitner notes how the lifting of restrictions on the adoption of Romanian babies gave rise to a booming business' (p. 57), and Alena Heitlinger detailing post-Communist changes for $\mathrm{Czech}$ and Slovak women cites instances of international 'commercial exploitation of women's sexual and childbearing capacity' in cases of international surrogacy and adoption (p. 104).

14. It is difficult to dramatize the trauma of infertility treatment without either falling into the trap of presenting the bourgeois, individualist, personal struggle of one wouldbe mother, or, appearing to argue a backlash return to motherhood as women's biological, essentialist destiny. It is important to note, therefore, the way in which Tess's struggle is staged through a Brechtian dramaturgy and within the motif of the cross-border adoption.

15. In Act One, for example, Wertenbaker introduces the figure of Natasha who is possibly a Bosnian refugee and is employed by Tess as a domestic. It becomes clear, however, that nobody really knows where she is from or who she is, and not until the end of the act is it considered important to find out.

16. Ruth Carter, A Yearning, unpublished manuscript, p. 42.

17. I am grateful to Alicia Arrizón for the proposal she made in our IFTR/FIRT feminist working group that I 'contest' in order to open up other ways of feminist 'seeing'.

18. Quoted in the programme notes to $A$ Yearning.

19. Ibid. This point is reinforced in moments when Amar cannot follow figurative speech. She is confused for example by the old woman who gossips with her asking 'when you step out doesn't the mangiest dog in the street start sniffing', and Amar, totally puzzled, asks 'Dog? What Dog?' (Carter, $A$ Yearning, p. 17).

20. Pragna Patel, 'Third Wave Feminism and Black 
Women's Activism' in Heidi Safia Mirza, ed., Black British Feminism (London: Routledge, 1997), p. 264. Patel also discusses the 'bounty hunter', and the tracking down of Asian women who, like Amar, are trying to escape from an oppressive, abusive or violent family 'home' (pp. 264-5).

21. Ghiarat Samalhar, 6 October 1995, p. 15.

22. This is typified, for example, by the way in which the Haymarket's 1995 Asian initiative /A Yearning was staged as part of this initiative) took place in the studio rather than the mainhouse space, and by the way in which $A$ Yearning takes its shape from a 'classic', white text.

23. Patel, 'Third Wave Feminism', p. 263.

24. One other 'choice' might be to take one's own life. Patel notes the relatively high suicide rates among Asian women in Britain between the ages of 16 and 35 which are three times the national average (p. 263). See also Patel's commentary on the Kiranjit Ahluwalia case, in which Ahluwalia was convicted for the murder of her violent husband (pp. 258-60), as a parallel to the fictional case of Amar's murder.

25. For an overview of Segal's own unconventional life and career, see Terry Grimley, 'Zohra's Stage Yearning Fulfilled', Birmingham Post, 26 September 1995, p. 10.

26. Amar was played by Sudha Bhuchar, known to audiences for her role in the BBC television soap opera, EastEnders.

27. Patel, 'Third Wave Feminism', pp. 267-8. 